\title{
Evidence for Cytokine-inducible Nitric Oxide Synthesis from L-Arginine in Patients Receiving Interleukin-2 Therapy
}

\author{
John B. Hibbs, Jr., ${ }^{\star}$ Christof Westenfelder, ${ }^{\ddagger}$ Read Taintor," Zdenek Vavrin," Carl Kablitz, ${ }^{\star}$ Robert L. Baranowski, ${ }^{\ddagger}$ \\ John H. Ward," Ronald L. Menlove," Martha P. McMurry," James P. Kushner," and Wolfram E. Samlowski" \\ Medical Service, Veterans Affairs Medical Center, and Divisions of Infectious Diseases, ${ }^{*}$ Hematology-Oncology, ${ }^{\S}$ and Nephrology, ${ }^{\ddagger}$ \\ Department of Internal Medicine, Clinical Research Center," and Division of Epidemiology and Biostatistics," \\ University of Utah School of Medicine, Salt Lake City, Utah 84132
}

\begin{abstract}
An interferon- $\gamma$, tumor necrosis factor, and interleukin-1-inducible, high-output pathway synthesizing nitric oxide (NO) from $\mathrm{L}$-arginine was recently identified in rodents. High-dose interleukin-2 (IL-2) therapy is known to induce the same cytokines in patients with advanced cancer. Therefore, we examined renal cell carcinoma (RCC; $n=5)$ and malignant melanoma (MM; $n$ = 7) patients for evidence of cytokine-inducible NO synthesis. Activity of this pathway was evaluated by measuring serum and urine nitrate (the stable degradation product of NO) during IL-2 therapy. IL-2 administration caused a striking increase in NO generation as reflected by serum nitrate levels (10- and 8-fold increase $[P<0.001, P<0.003]$ for RCC and MM patients, respectively) and 24-h urinary nitrate excretion (6.5- and 9-fold increase [both $P<0.001$ ] for RCC and MM patients, respectively). IL-2-induced renal dysfunction made only a minor contribution to increased serum nitrate levels. Metabolic tracer studies using L-[guanidino- ${ }^{15} \mathbf{N}_{2}$ ] ]arginine demonstrated that the increased nitrate production was derived from a terminal guanidino nitrogen atom of L-arginine. Our results showing increased endogenous nitrate synthesis in patients receiving IL2 demonstrate for the first time that a cytokine-inducible, highoutput L-arginine/NO pathway exists in humans. (J. Clin. Invest. 1992. 89:867-877.) Key words: acute renal failure $\bullet$ malignant melanoma $\bullet$ nitrate $\cdot$ nitrite $\bullet$ renal cell carcinoma
\end{abstract}

\section{Introduction}

Many host responses to microbial agents and neoplastic cells are mediated by cytokines. Interleukin 2 (IL-2), which is primarily synthesized by activated $\mathrm{T}$ lymphocytes, has a central role in the development of cell-mediated immunity (1) and is a key factor in the induction of a complex network of cytokines that include tumor necrosis factor/cachetin (TNF), ${ }^{1}$ inter-

Address reprint requests to Dr. Hibbs, Division of Infectious Diseases, School of Medicine, University of Utah, Room 4B322, 50 North Medical Drive, Salt Lake City, UT 84132.

Received for publication 26 July 1991 and in revised form 6 November 1991.

1. Abbreviations used in this paper: BUN, blood urea nitrogen; FE, fractional excretion; GC/MS, gas chromatography-mass spectrometry; LAK, lymphokine-activated killer; MM, malignant melanoma; RCC, renal cell carcinoma; TNF, tumor necrosis factor; TPN, total parenteral nutrition.

J. Clin. Invest.

(c) The American Society for Clinical Investigation, Inc.

$0021-9738 / 92 / 03 / 0867 / 11 \quad \$ 2.00$

Volume 89, March 1992, 867-877 feron- $\gamma$ (IFN $\gamma)$, interleukin 1 (IL-1), and interleukin 6 (2-7). It was observed, in both mice and humans, that normal resting lymphocytes treated with high concentrations of IL-2 developed the ability to kill a wide range of syngeneic and allogeneic tumor cells (8). IL-2-activated cells were functionally defined as lymphokine-activated killer (LAK) cells and administration of IL-2 plus LAK cells to mice caused regression of established syngeneic tumors (9). Clinical trials of IL-2 plus LAK cells or of IL-2 alone demonstrated objective regressions in $\sim 25-33 \%$ of patients including 5-10\% complete remissions in patients with advanced melanoma or renal cell carcinoma (10). Clinical use of IL-2 therapy, with or without LAK cells, has been limited by the low rate of complete remissions and by severe toxicity that requires intensive care monitoring. Patients receiving IL-2 therapy often develop potentially life-threatening side effects that include fever, chills, hypotension, capillary leak syndrome, as well as evidence of multiple organ system dysfunction, specifically including acute renal insufficiency and cholestatic jaundice (10).

Studies of rodent cytotoxic activated macrophages as an effector component of cell-mediated immunity resulted in the identification of a cytokine (IFN $\gamma$ and TNF)-inducible pathway that was capable of producing high levels of nitric oxide (NO) and L-citrulline synthesis from L-arginine (11-18) (for reviews, see references 19 and 20). NO is a short-lived paramagnetic lipid-soluble gas which, when present in high concentration in the cellular environment, causes widespread ironsulfur nitrosyl complex formation that inhibits certain iron-dependent enzymes $(21,22)$ (Fig. 1). NO has been shown to be a biochemical effector of $\mathrm{L}$-arginine-dependent cell-mediated immune responses to neoplastic cells $(11-13,16,17,19)$ as well as to certain helminths and intracellular pathogens $(20,23-29)$ in rodent cells in vitro.

A constitutive low-output pathway synthesizing small amounts of $\mathrm{NO}$ and L-citrulline from L-arginine was also recently identified (30-33). NO synthesized from $L$-arginine by the constitutive NO synthase functions as an intercellular and/ or intracellular signal. For example, NO synthesized by the constitutive isoenzyme of endothelial cells targets a heme moiety associated with soluble guanylate cyclase of vascular smooth muscle cells and mediates functional linkage between these two cell types (34). Examples of constitutive NO synthase activity include modulation of vascular tone (30) and neurotransmission (31-33).

NO synthesized by either isoenzyme undergoes oxidative degradation to the stable inorganic nitrogen oxides nitrite $\left(\mathrm{NO}_{2}^{-}\right)$and nitrate $\left(\mathrm{NO}_{3}^{-}\right) . \mathrm{NO}_{2}^{-}$entering the vascular system reacts rapidly with oxyhemoglobin (35). This results in stoichiometric formation of methemoglobin and $\mathrm{NO}_{3}^{-}$from oxyhemoglobin and $\mathrm{NO}_{2}^{-}$(see Fig. 1). Therefore, NO synthesized 
[1]

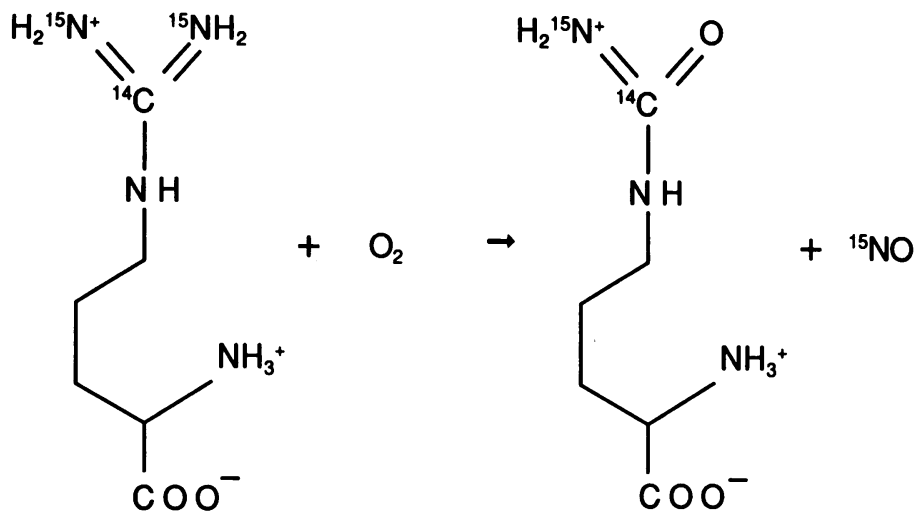

[2]

$2^{15} \mathrm{NO}+\mathrm{O}_{2} \rightarrow 2^{15} \mathrm{NO}_{2}$

[3]

$2{ }^{15} \mathrm{NO}_{2}+\mathrm{H}_{2} \mathrm{O} \rightarrow{ }^{15} \mathrm{NO}_{2}^{-}+{ }^{15} \mathrm{NO}_{3}^{-}+2 \mathrm{H}^{+}$

[4]

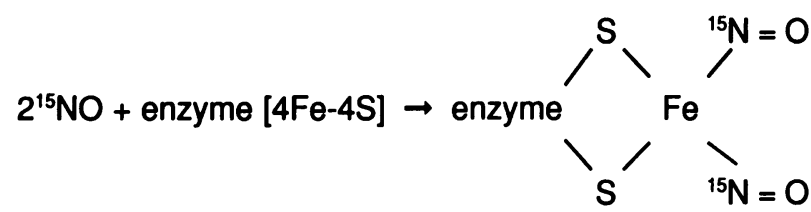

[5]

$4 \mathrm{HbO}_{2}+4 \mathrm{NO}_{2}^{-}+4 \mathrm{H}^{+} \rightarrow 4 \mathrm{Hb}^{+}+4 \mathrm{NO}_{3}^{-}+\mathrm{O}_{2}+2 \mathrm{H}_{2} \mathrm{O}$
Figure 1. Precursor and products of the biological synthesis of inorganic nitrogen oxides and $\mathrm{L}$-citrulline from $\mathrm{L}$-arginine. ${ }^{15} \mathrm{~N}$-containing products derived from $\mathrm{L}-\left[{ }^{15} \mathrm{~N}\right]$ arginine were identified by GC/MS $(13-15,30)$ electron paramagnetic resonance spectroscopy $(21,22)$ except for nitrogen dioxide $\left(\mathrm{NO}_{2}\right)$, which was detected by another method (13). The direct synthesis of $\mathrm{L}$-citrulline from $\mathrm{L}$-arginine has been identified with several techniques (12-15, 58). The experiments utilizing L-[guanidino${ }^{14} \mathrm{C}$ ]arginine $(13,58)$ are illustrated in the figure. NO formed by reaction [1] can undergo oxidative degradation in aqueous solution (reactions [2] and [3] or react with nonheme iron associated with sulfur atoms to form nitrosyliron-sulfur complexes (reaction [4]). Although not shown, certain other forms of intracellular iron also complex with NO. (Hibbs et al., unpublished data). $\mathrm{NO}_{2}^{-}$entering the vascular system reacts rapidly with oxyhemoglobin (35). This results in the stoichiometric formation of methemoglobin and $\mathrm{NO}_{3}^{-}$from oxyhemoglobin and $\mathrm{NO}_{2}^{-}$(reaction [5]). from a terminal guanidino nitrogen atom of $\mathrm{L}$-arginine is detected in serum or urine as $\mathrm{NO}_{3}^{-}$. The study reported here was undertaken to examine ( $a$ ) whether IL-2 administration to patients with cancer caused a rise in NO synthesis from L-arginine; $(b)$ whether urine and serum $\mathrm{NO}_{3}^{-}$levels could serve as markers of IL-2-stimulated NO generation; and $(c)$ the extent that IL-2-induced renal dysfunction $(36,37)$ contributed to elevations in serum $\mathrm{NO}_{3}^{-}$levels.

\section{Methods}

Subjects. The study protocol was reviewed and approved by the University of Utah School of Medicine Institutional Review Board and written informed consent was obtained from all patients. The patients $(n$ $=12$ ) were admitted to the University Hospital's Clinical Research Center for study and treatment (Table I). The patients had metastatic malignant melanoma (MM [ $n=7$; mean age $44 \mathrm{yr}$, range 24-63]) or metastatic renal cell carcinoma (RCC $[n=5$; mean age $53 \mathrm{yr}$, range 39-63]) that was unresponsive to conventional treatment. All the patients with RCC had fully recovered from a unilateral nephrectomy before IL-2 therapy. There were three female MM patients and one female RCC patient enrolled in this study.

High-dose bolus IL-2 treatment with or without LAK cells. Patient eligibility included the following criteria: pathologic confirmation of tumor histology, measurable disease, Karnofsky performance status $>70 \%$, normal stress multiple-uptake gated acquisition or thallium scan, normal pulmonary function (forced expiratory volume in [FEV 1 $>75 \%$ of predicted), normal bone marrow, and liver and renal func- tion. The creatinine clearance of $\mathrm{MM}$ patients was normal (mean $=122 \mathrm{ml} / \mathrm{min}$ ). The creatinine clearance of RCC patients with unilateral nephrectomies was $\sim 50 \%$ of normal (mean $=59 \mathrm{ml} / \mathrm{min}$ ). Exclusion criteria included pregnancy, active infection (including HIV), steroid therapy, organ allografts, brain metastases, or prior malignancy. All patients were treated for anticipated IL-2 toxicity with acetaminophen $650 \mathrm{mg}$ p.o. every $4 \mathrm{~h}$, indomethacin $25 \mathrm{mg}$ p.o. every $6 \mathrm{~h}$, and ranitidine $150 \mathrm{mg}$ i.v. every $12 \mathrm{~h}$. Patients also received meperidine 25-50 mg every $4 \mathrm{~h}$ i.v. as needed for chills due to IL-2 or LAK cell administration, as well as symptomatic treatment for pruritus, vomiting, or diarrhea as required. Each patient received highly purified recombinant human IL-2 from Escherichia coli (sp act $18 \times 10^{6} \mathrm{IU} / \mathrm{mg}$ ) generously provided by Cetus Corp., Emeryville, CA, at $600,000 \mathrm{IU} / \mathrm{kg}$ i.v. every $8 \mathrm{~h}$ on days $1-5$ (induction course). The IL-2 used in these experiments contained $<0.012 \mathrm{ng} / \mathrm{ml}$ LPS by Limulus amebocyte lysate assay $\left(18 \times 10^{6} \mathrm{IU}\right.$ of IL-2 in $1 \mathrm{ml}$ of PBS). Patients received either IL-2 alone, or IL-2 in conjunction with LAK cells during days 11-15 (consolidation course), Table I. All five patients with RCC received induction IL-2 therapy. Patient 1 was not given a consolidation course of IL-2 because of a severe decrease in renal function.

Patients who randomized to IL-2 with LAK cells were leukapheresed for $5 \mathrm{~h} / \mathrm{d}$ on days $7-10$. The cells from each pheresis were cultured for 3-4 d in vitro in serum-free Ex Vivo-10 medium (M. A. Bioproducts, Walkersville, MD) containing $2 \mathrm{mM} \mathrm{L}$-glutamine and 1,500 $\mathrm{U}$ of IL- $2 / \mathrm{ml}$, and readministered to the patient in a single i.v. daily infusion, (in $250 \mathrm{ml}$ of saline containing $5 \%$ albumin and 50,000 U of IL-2) during the second (consolidation) IL-2 treatment course on days 11 , 12, and 14. Doses of IL-2 were held for National Cancer Institute common toxicity grade III or IV toxicity, usually oliguria, hypotension 
Table I. Characteristics of Patients Treated with $I L-2$

\begin{tabular}{|c|c|c|c|c|c|c|c|c|}
\hline \multirow[b]{2}{*}{ Patient } & \multirow[b]{2}{*}{ Diagnosis* } & \multirow[b]{2}{*}{ Age/Sex } & \multirow{2}{*}{$\begin{array}{l}\text { Date of } \\
\text { treatment }\end{array}$} & \multicolumn{2}{|c|}{ IL-2 doses } & \multirow{2}{*}{$\begin{array}{l}\text { Total } \\
\text { IU IL-2 } \\
\times 10^{6}\end{array}$} & \multirow{2}{*}{$\begin{array}{l}\text { Total } \\
\text { LAK cells } \\
\times 10^{10}\end{array}$} & \multirow{2}{*}{$\begin{array}{l}\text { Clinical response } \\
\text { (duration) }^{\ddagger}\end{array}$} \\
\hline & & & & Induction & Consolidation & & & \\
\hline & & & & & & & & $m o$ \\
\hline 1 & $\mathrm{RCC}$ & $63 / \mathrm{M}$ & $8 / 8 / 89$ & 10 & 0 & 456 & 0 & PD \\
\hline 2 & RCC & $51 / \mathrm{M}$ & $9 / 5 / 89$ & 13 & 7 & 2856 & 23.8 & PD \\
\hline 3 & $\mathrm{RCC}$ & $60 / \mathrm{M}$ & $9 / 26 / 89$ & 11 & 8 & 935 & 0 & $\mathrm{CR}(>22)$ \\
\hline 4 & RCC & $39 / \mathrm{F}$ & $11 / 21 / 89$ & 12 & 7 & 627 & 12.4 & PD \\
\hline $5 a^{8}$ & $\mathbf{M M}$ & $24 / F$ & $2 / 20 / 90$ & 11 & 7 & 702 & 9.2 & - \\
\hline $5 b$ & MM & & $5 / 29 / 90$ & 13 & 6 & 741 & 8.8 & PR (11) \\
\hline 6 & $\mathbf{M M}$ & $45 / M$ & $3 / 6 / 90$ & 12 & 11 & 1173 & 14.0 & PD \\
\hline 7 & $\mathrm{RCC}$ & $54 / \mathrm{M}$ & $3 / 13 / 90$ & 7 & 3 & 444 & 6.9 & SD (7) \\
\hline 8 & $\mathbf{M M}$ & $63 / \mathrm{F}$ & $4 / 17 / 90$ & 12 & 9 & 1046 & 0 & PD \\
\hline 9 & MM & $45 / F$ & $6 / 2 / 90$ & 11 & 6 & 745 & 0 & PR (2) \\
\hline 10 & MM & $48 / M$ & $6 / 26 / 90$ & 14 & 13 & 1118 & 18.1 & $\mathrm{SD}(2.5)$ \\
\hline 11 & MM & $51 / \mathrm{M}$ & $7 / 3 / 90$ & 13 & 10 & 773 & 10.7 & PD \\
\hline 12 & MM & $35 / \mathrm{M}$ & $9 / 19 / 90$ & 14 & 5 & 744 & 0 & PD \\
\hline
\end{tabular}

* RCC, renal cell carcinoma; and MM, malignant melanoma.

‡ $\mathrm{PD}$, progressive disease; $\mathrm{SD}$, stable disease; $\mathrm{PR}$, partial response; and $\mathrm{CR}$, complete response.

${ }^{\$}$ Patient 5 was administered two complete courses of IL-2.

requiring $>4 \mu \mathrm{g} / \mathrm{kg} \cdot \min$ dopamine, severe hypoxia, or neurologic toxicity. Central venous pressure and systemic blood pressure were measured every $4 \mathrm{~h}$, during hospitalization. Our patients were monitored closely for evidence of infection (urine, blood, and intravascular device cultures for oral temperatures $>38^{\circ} \mathrm{C}$ ). Three episodes of line infection were documented in two patients (coagulase-negative Staphylococcus [patient 4] and coagulase-negative Staphylococcus followed by Proteus mirabilis [patient 6]).

Nutrition regimen. All patients received parenteral nutrition (TPN) infused via a central line. The TPN solution (a mixture of equal parts of 8.5\% Aminosyn [Abbott Laboratories, North Chicago, IL] and 50\% dextrose plus standard vitamin and mineral solutions, and infused at a rate of $\sim 100 \mathrm{ml} / \mathrm{h}$ [standard TPN regimen]) consistently tested negative for $\mathrm{NO}_{2}^{-}$and $\mathrm{NO}_{3}^{-}$. Lipids (Liposyn, Abbott Laboratories) were given two times per week. The standard TPN regimen provided $10.2 \mathrm{~g}$ of $\mathrm{L}$-arginine daily.

Low $\mathrm{NO}_{2}^{-} / \mathrm{NO}_{3}^{-}$foods were also provided in small amounts to those patients desiring oral feedings. Carnation Instant Breakfast (Carnation Co., Los Angeles, CA) (laboratory analysis showed $<0.3 \mathrm{mg}$ of $\mathrm{NO}_{3}^{-}$ per serving), or other low $\mathrm{NO}_{2}^{-} / \mathrm{NO}_{3}^{-}$foods were supplied, based on limited information on food $\mathrm{NO}_{2}^{-} / \mathrm{NO}_{3}^{-}$content $(38,39)$. The following food groups were excluded: cured meats, malt, vegetables raw or cooked, including potatoes, melons, fish, imported cheese, and any fermented foods. The diet included milk, ice cream and domestic cheese, eggs, breads and cereals (including whole kernel corn), fresh meats (chicken, turkey, beef and pork), legumes, other fruits, hard candy and carbonated beverages, sugar, coffee, salt, and pepper. Daily enteral intake was also recorded and included in the calorie counts.

Measurement of urine and blood $\mathrm{NO}_{3}^{-}$. Sequential 24-h urine specimens were collected throughout the study period. Bacterial growth in the urine during the collection period was prevented by placing $200 \mathrm{ml}$ of 2-propanol into a 3-liter collection bottle. The samples were frozen at $-80^{\circ} \mathrm{C}$ until a $1: 10$ dilution of urine was assayed for $\mathrm{NO}_{3}^{-}$as previously described $(24,40)$. The 2-propanol did not affect the enzymatic conversion of $\mathrm{NO}_{3}^{-}$to $\mathrm{NO}_{2}^{-}$by the $E$. coli $\mathrm{NO}_{3}^{-}$reductase. Serum was diluted 1:1 with $\mathrm{NO}_{2}^{-} / \mathrm{NO}_{3}^{-}$free distilled water and then ultrafiltered (Ultrafree MC microcentrifuge device, UFC3 LGC NB, Millipore Corp., Bedford, MA) at $2,000 \mathrm{~g}$ for $120 \mathrm{~min}$. $\mathrm{NO}_{3}^{-}$in the filtrate was reduced to $\mathrm{NO}_{2}^{-}$by mixing $80 \mathrm{ml}$ with $80 \mathrm{ml} E$. coli $\mathrm{NO}_{3}^{-}$reductase suspension prepared and then incubated for $1 \mathrm{~h}$ at $37^{\circ} \mathrm{C}$. The $E$. coli $\mathrm{NO}_{3}^{-}$reductase had no $\mathrm{NO}_{2}^{-}$reductase activity when prepared as described (24). The reaction mixture was centrifuged $(12,000 \mathrm{rpm}, \mathrm{Mi}-$ crofuge, Beckman Instruments, Inc., Fullerton, CA) for $5 \mathrm{~min}$. Supernatant $(50 \mathrm{ml})$ was added to $100 \mathrm{ml}$ of Griess reagent (24). Absorbance (A540) was measured on a microplate reader (Dynatech Laboratories, Inc., Chantilly, VA).

Administration of the stable nonradioactive isotope $\mathrm{L}$-arginine $\mathrm{HCl}$ (guanidino ${ }^{15} \mathrm{~N}_{2}, 70 \%$ ). The material supplied by Cambridge Isotope Laboratories, Woburn, MA, contained 70\% L-[guanidino- ${ }^{15} \mathrm{~N}_{2}$ ] arginine ( $\mathrm{L}-\left[{ }^{15} \mathrm{~N}\right]$ arginine) as determined by potentiometric titration (Galbraith Laboratories, Knoxville, TN). HPLC and nuclear magnetic resonance analysis showed $1.5 \% \mathrm{~L}$-ornithine and $<2 \%$ of the optical isomer $\mathrm{D}$-[guanidino ${ }^{15} \mathrm{~N}_{2}$ ] ]arginine which is not a substrate for the cytokine-induced $\mathrm{L}$-arginine/NO pathway $(11,12)$. The remaining and major other component was unlabeled ammonium chloride. A $70 \mathrm{mM}$ stock solution of $\mathrm{L}-\left[{ }^{15} \mathrm{~N}\right]$ arginine prepared in sterile pyrogen-free water contained $<1 \mathrm{ng} / \mathrm{ml}$ of lipopolysaccharide (LPS) as measured by the Limulus amebocyte lysate assay. This stock solution was filtered three times $(0.22 \mathrm{mM}$, Millipore Corp.) and sterility was confirmed by culture on blood agar. $\mathrm{L}-\left[{ }^{15} \mathrm{~N}\right]$ arginine $\mathrm{HCl}$ was added to a TPN solution containing a 1:1 mixture of 5.4\% Nephramine (an essential amino acid mixture that lacks L-arginine; Kendall McGraw Laboratories, Inc., Irvine, $\mathrm{CA}$ ) and $50 \%$ dextrose plus vitamins/electrolytes. The standard TPN mixture was discontinued and the $\mathrm{L}-\left[{ }^{15} \mathrm{~N}\right]$ arginine/Nephramine containing TPN mixture $(2,400 \mathrm{ml})$ infused over a $24-\mathrm{h}$ period. The standard TPN regimen was resumed upon completion of the $L-\left[{ }^{15} \mathrm{~N}\right]-$ arginine infusion. The patients tolerated the $\mathrm{L}-\left[{ }^{15} \mathrm{~N}\right]$ arginine infusions without incident or adverse effects. All calculations of ${ }^{15} \mathrm{~N}$ enrichment of serum $\mathrm{NO}_{3}^{-}$, urine $\mathrm{NO}_{3}^{-}$, and urine urea were based on the administration of a $70 \% \mathrm{~L}-\left[{ }^{15} \mathrm{~N}\right]$ arginine solution.

${ }^{15} \mathrm{~N}$ enrichment of serum $\mathrm{NO}_{3}^{-}$, urine $\mathrm{NO}_{3}^{-}$, and urine urea. Atom percent excess of urine and serum $\left[{ }^{15} \mathrm{~N}_{\mathrm{NO}_{3}^{-}}\right.$and $\left[{ }^{15} \mathrm{~N}\right]$ urea was measured by gas chromatography-mass spectrometry (GC/MS) (model 5971, Hewlett-Packard Co., Palo Alto, CA), using electron ionization as previously described $(41,42)$. GC/MS analysis was performed by Dr. David A. Wagner, Metabolic Solutions Inc., Acton, MA.

Determination of renal function. Glomerular filtration rate was monitored throughout by daily determination of endogenous creati- 
nine clearance. Renal handling of $\mathrm{NO}_{3}^{-}$, urea, sodium, and water was assessed as previously reported $(43,44)$.

Statistical analysis. Statistical analysis was conducted using stepwise regression to evaluate differences among patients, followed by isolation of treatment effects as post-patient factors. Stepwise analysis of covariance procedure was used to compare periods of IL-2 administration vs. periods when patients were not receiving the drug. Two levels of prior comparisons were used. The first level tested for the presence of a linear (monotonically increasing or decreasing) trend within the four treatment phases of the study (two IL-2 and two offdrug) $(45,46)$. In the second level, paired comparisons for differences among treatments were conducted, each averaging across the $5 \mathrm{~d}$ of observations within a treatment phase. The first compared the first IL-2 treatment with the first off-drug phase. The second compared the second IL-2 treatment with the second off-drug phase. The third contrast compared the first two treatment phases with the second two treatment phases and constituted a test of the reversibility and reproducibility of IL-2 therapy. Additional analyses were conducted to compare all possible pairs of treatments. Means for the four treatment phases were subjected to analysis of variance for repeated measurements. In case of overall significance, Newman-Keul's pairwise comparison of the differences between treatments was performed. All data are expressed as mean \pm SE. A $P$ value of $<0.05$ was taken to indicate significant differences.

\section{Results}

Baseline serum $\mathrm{NO}_{3}^{-}$and 24- $h$ urine $\mathrm{NO}_{3}^{-}$output. Serum $\mathrm{NO}_{3}^{-}$ levels in six normal control individuals (four males and two females; mean age $38 \mathrm{yr}$ ) was $32 \pm 4 \mu \mathrm{mol} / \mathrm{liter}$. The control individuals consumed a low nitrite $\left(\mathrm{NO}_{2}^{-} / \mathrm{NO}_{3}^{-}\right)$oral diet for 24 $h$ and then fasted overnight ( $12 \mathrm{~h}$ ) before donating blood for the $\mathrm{NO}_{3}^{-}$assay. In the current study, pretreatment serums were assayed for $\mathrm{NO}_{3}^{-}$. Baseline serum $\mathrm{NO}_{3}^{-}$for $\mathrm{MM}$ patients was $32 \pm 3.3 \mu \mathrm{mol} / \mathrm{liter}(n=9)$ and for RCC patients $36 \pm 3.2 \mu \mathrm{mol} /$ liter $(n=5)$. The mean 24-h urinary $\mathrm{NO}_{3}^{-}$output for the patients on TPN before initiation of IL-2 therapy was $600 \pm 80$ $\mu \mathrm{mol}(n=5)$ for MM patients and 521 $(71 \mu \mathrm{mol}(n=3)$ for RCC patients. This was similar to urinary $\mathrm{NO}_{3}^{-}$excretion $(690$ $\mu \mathrm{mol} / 24 \mathrm{~h}$ ) in eight healthy subjects with unrestricted activity (mean age $21 \mathrm{yr}$ ) on a low protein and low $\mathrm{NO}_{2}^{-} / \mathrm{NO}_{3}^{-}$oral diet (daily $\mathrm{NO}_{3}^{-}$ingestion $<180 \mu \mathrm{mol}$ ) (47).

Effect of IL-2 therapy on serum $\mathrm{NO}_{3}^{-}$levels. The 5-d induction course of IL-2 therapy caused a significant rise of serum $\mathrm{NO}_{3}^{-}$levels in both RCC patients (Fig. 2, left, panel $a$ ) and MM patients (Fig. 2, right, panel $a$ ). The results for RCC and MM patients are presented separately because of the possible effects of unilateral nephrectomy on serum and urinary $\mathrm{NO}_{3}^{-}$levels. Serum $\mathrm{NO}_{3}^{-}$of RCC patients increased from a baseline level of $36 \pm 3.2$ to $106 \pm 16 \mu \mathrm{mol} /$ liter on day 3 of therapy, followed by a further increase on day 5 (313 $\pm 55 \mathrm{mmol} / \mathrm{liter})$, and peaked on day $7(353 \pm 31 \mu \mathrm{mol} /$ liter $)$. This 10 -fold rise in serum $\mathrm{NO}_{3}^{-}$was highly significant $(P<0.001)$. The overall pattern of serum $\mathrm{NO}_{3}^{-}$changes in $\mathrm{MM}$ patients was similar to that observed in $\mathrm{RCC}$ patients. Serum $\mathrm{NO}_{3}^{-}$levels increased from the baseline of $32 \pm 3.3 \mu \mathrm{mol} /$ liter to $57 \pm 35,189 \pm 48$, and $247 \pm 96$ on days 4,5 , and 6, respectively $(P<0.003)$. The highest individual serum $\mathrm{NO}_{3}^{-}$level recorded was $646 \mu \mathrm{mol} /$ liter on day 7 . Serum $\mathrm{NO}_{3}^{-}$ decreased to $25 \pm 4 \mu \mathrm{mol} / \mathrm{liter}$ by day 11 when consolidation IL-2 therapy was started. During the interval between the induction course and consolidation course of IL-2, serum $\mathrm{NO}_{3}^{-}$ levels fell more slowly in RCC patients than in MM patients. During the second half of the treatment course peak serum
$\mathrm{NO}_{3}^{-}$for $\mathrm{MM}$ patients was $122 \pm 23 \mu \mathrm{mol} / \mathrm{liter}$ (day 15). The peak serum $\mathrm{NO}_{3}^{-}$level during the consolidation course of IL-2 was significantly less than during the induction course both in RCC $(P<0.02)$ and MM $(P<0.05)$ patients.

Effect of IL-2 therapy on endogenous $\mathrm{NO}_{3}^{-}$synthesis as determined by 24- $h$ urinary $\mathrm{NO}_{3}^{-}$excretion. Daily $\mathrm{NO}_{3}^{-}$excretion paralleled serum $\mathrm{NO}_{3}^{-}$levels. Fig. 2, both panels $b$, show the mean 24-h urinary $\mathrm{NO}_{3}^{-}$excretion for patients with $\mathrm{RCC}$ and MM, respectively. 24-h $\mathrm{NO}_{3}^{-}$excretion rose significantly ( $P$ $<0.001)$ from a baseline value of $521 \pm 71 \mu \mathrm{mol}$ to a peak of $3,376 \pm 470.4 \mu \mathrm{mol} / 24 \mathrm{~h}$ on day $7(P<0.001)$ in five patients with RCC. By day 11, when the second course of IL-2 was started, $\mathrm{NO}_{3}^{-}$excretion returned to $637.5 \pm 72.85 \mu \mathrm{mol} / 24 \mathrm{~h}$, a value close to the control level. As was observed during the first IL-2 course, $\mathrm{NO}_{3}^{-}$excretion increased during the second IL-2 infusion, again peaking $(2,014.9 \pm 608.5 \mu \mathrm{mol} / 24 \mathrm{~h} ; P<0.05) 2$ $\mathrm{d}$ after completion of therapy. Thereafter, $\mathrm{NO}_{3}^{-}$excretion returned toward baseline. The consolidation course of IL-2 or IL-2 plus LAK cell therapy produced a significantly smaller increase in 24-h mean urine $\mathrm{NO}_{3}^{-}$output than the induction course $(P<0.001)$.

In eight treatment courses in seven patients with MM (patient 5 had two complete courses of IL-2 therapy separated by a 3-mo interval), the excretion of $\mathrm{NO}_{3}^{-}$increased significantly from baseline $(600 \pm 80 \mu \mathrm{mol} / 24 \mathrm{~h})$ to $1,372 \pm 271 \mu \mathrm{mol} / 24 \mathrm{~h}$ during the first $24 \mathrm{~h}$ of IL-2 therapy $(P<0.05)$ and stabilized at this level until day 6 when urine $\mathrm{NO}_{3}^{-}$excretion rose $(3,368 \pm 1,041$ and $5,401 \pm 1,436 \mu \mathrm{mol} / 24 \mathrm{~h}$ on days 6 and 7 , respectively $[P<0.001])$. The mean $24-\mathrm{h}$ output of $\mathrm{NO}_{3}^{-}$then fell gradually to near baseline level ( $766 \mu \mathrm{mol} / 24 \mathrm{~h})$ by day 11 . The highest 24-h urine excretion of $\mathrm{NO}_{3}^{-}$by an individual patient was $11,824 \mu \mathrm{mol}$ on day 7 . After reinstitution of IL-2 with and without LAK cell administration (days 11-17), urine $\mathrm{NO}_{3}^{-}$ again increased (mean values of $2,041 \mu \mathrm{mol} /$ liter on day 16 and $2,670 \mu \mathrm{mol} /$ liter on day 17$)$ but did not reach levels observed during the priming course of IL-2 $(P<0.003)$. The differences in 24-h urine $\mathrm{NO}_{3}^{-}$output and serum $\mathrm{NO}_{3}^{-}$levels between the induction and consolidation courses of IL-2 could be related, in part, to the fact that both MM and RCC patients received fewer infusions of IL-2 during the consolidation course because of more severe toxic side effects. MM and RCC patients received a mean of 12.5 and 10.6 priming IL-2 infusions and 8.5 and 5 consolidation infusions of 14 possible doses in each treatment course (Table I).

Effect of IL-2-induced changes in renal function on serum $\mathrm{NO}_{3}^{-}$levels and 24-h urine $\mathrm{NO}_{3}^{-}$excretion. The data were further analyzed in order to determine whether the IL-2-induced increase in serum $\mathrm{NO}_{3}^{-}$resulted from a primary rise in $\mathrm{NO}_{3}^{-}$ production or from decreased renal $\mathrm{NO}_{3}^{-}$excretion (see Fig. 2, panels $c, d, e$ ). This distinction was important since IL-2 administration caused reproducible decreases in creatinine clearance that could have contributed to $\mathrm{NO}_{3}^{-}$retention and thus elevation of serum $\mathrm{NO}_{3}^{-}$levels $(36,37)$. The data summarized in Fig. 2 (left) demonstrate that the observed increases in serum $\mathrm{NO}_{3}^{-}$ levels of RCC patients resulted from a primary rise in $\mathrm{NO}_{3}^{-}$ production and not from a major decrease in renal $\mathrm{NO}_{3}^{-}$excretion. This is concluded because the increases in serum and urine $\mathrm{NO}_{3}^{-}$(panels $a$ and $b$ ) were accompanied by parallel elevations in serum $\mathrm{NO}_{3}^{-} /$creatinine (threefold increase; $P$ $<0.005$ ), serum $\mathrm{NO}_{3}^{-}$/blood urea nitrogen (BUN) (eightfold increase; $P<0.001$ ) and urine $\mathrm{NO}_{3}^{-} /$creatinine (fivefold increase; $P<0.02$ ) ratios (panels $c$ through $e$ ). In MM patients 

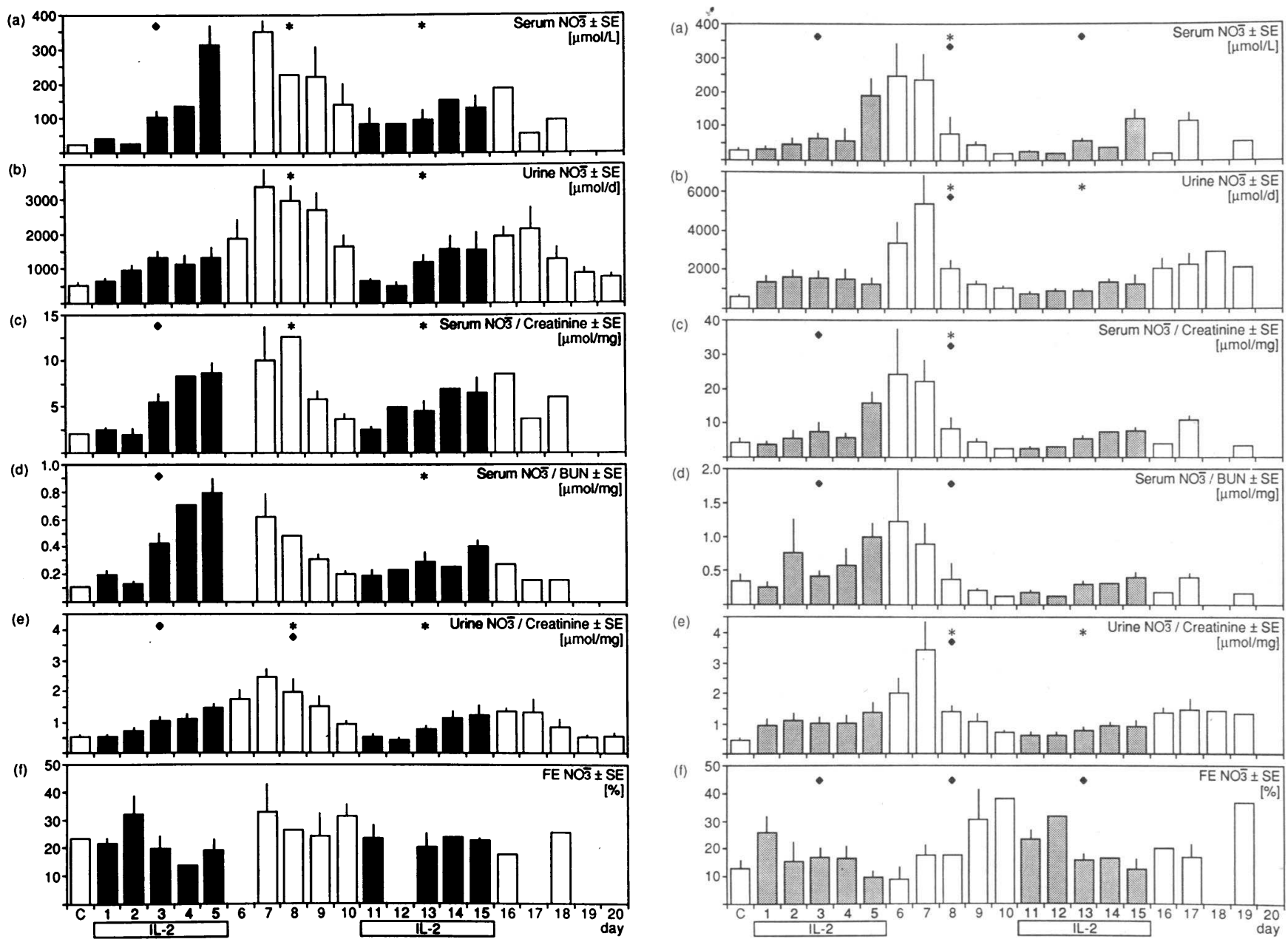

Figure 2. Serum $\mathrm{NO}_{3}^{-}$levels and renal $\mathrm{NO}_{3}^{-}$handling in (left) RCC patients $(n=5)$ and (right) MM patients $(n=7)$ treated with two courses of IL-2. Open bars denote control days and the two recovery periods after the discontinuation of IL-2. Closed bars denote days of IL-2 administration (induction and consolidation courses). Values are expressed as means \pm SEM. Diamond ( $\bullet$ ) indicates that the quantitative change of a depicted variable during IL-2 therapy (induction and consolidation courses) and during interruption or termination of IL-2 therapy is significant (at least $P<0.05$ ), or in other words that the slope of a given change is significantly different from "zero." Asterisk $\left({ }^{*}\right)$ indicates that values measured during a given IL-2 or recovery period are significantly different (at least $P<0.05$ ) from those in the immediately preceding treatment or recovery period, respectively. $\mathrm{L}$, liter.

(Fig. 2, right) serum $\mathrm{NO}_{3}^{-}$(panel $a$ ) and urinary $\mathrm{NO}_{3}^{-}$excretion (panel $b$ ) also increased in parallel with the ratios of serum $\mathrm{NO}_{3}^{-}$/creatinine (panel $c ; P<0.005$ ), serum $\mathrm{NO}_{3}^{-} / \mathrm{BUN}$ (panel $d ; P<0.003$ ) and urine $\mathrm{NO}_{3}^{-} /$creatinine (panel $e, P<0.004$ ) ratios. The significant rise of the former two ratios indicates that the elevation in serum $\mathrm{NO}_{3}^{-}$exceeded simultaneous increases in creatinine and BUN induced by IL-2. The portion of filtered $\mathrm{NO}_{3}^{-}$that is excreted, remained relatively unchanged in RCC patients as evidenced by the fractional excretion (FE) of $\mathrm{NO}_{3}^{-}$(Fig. 2, left, panel $f$ ). The pattern of the $\mathrm{FE} \mathrm{NO}_{3}^{-}$for $\mathrm{MM}$ differed somewhat from that observed for the RCC patients. Fig. 2, right, panel $f$, shows that the fractional excretion of $\mathrm{NO}_{3}^{-}$ fell significantly during both courses of IL-2 therapy and rose during the first recovery period. These results suggest that marked IL-2-induced generation and modest $\mathrm{NO}_{3}^{-}$retention contributed to the overall rise in serum $\mathrm{NO}_{3}^{-}$levels.

Origin of $\mathrm{NO}_{3}^{-}$synthesized in response to $\mathrm{IL}-2$ treatment in humans. Inorganic nitrogen oxides synthesized by cytokinetreated rodent macrophages are derived from a terminal guani- dino nitrogen atom of L-arginine (see Fig. 1). In order to determine whether $\mathrm{NO}_{3}^{-}$synthesized by humans in response to IL-2 originated from the same precursor molecule, we administered intravenous $\mathrm{L}-\left[{ }^{15} \mathrm{~N}\right]$ arginine to two patients. The synthesis of $\left[{ }^{15} \mathrm{~N}\right] \mathrm{NO}_{3}^{-}$from $\mathrm{L}-\left[{ }^{15} \mathrm{~N}\right]$ arginine was compared to that of $\left[{ }^{15} \mathrm{~N}\right]$ urea, a molecule known to be exclusively derived from the guanidino portion of $\mathrm{L}$-arginine via the arginase reaction of the urea cycle (19). Fig. 3, panels $a$ and $b$, shows the serum $\mathrm{NO}_{3}^{-}$ levels and the 24-h urine output of $\mathrm{NO}_{3}^{-}$of patient 10 with $\mathrm{MM}$ who was administered intravenous $\mathrm{L}_{-}\left[{ }^{15} \mathrm{~N}\right]$ arginine. Patient 10 had the characteristic increase of IL-2-induced $\mathrm{NO}_{3}^{-}$synthesis as reflected by total 24-h urine $\mathrm{NO}_{3}^{-}$output and serum $\mathrm{NO}_{3}^{-}$ levels. $\mathrm{L}-\left[{ }^{15} \mathrm{~N}\right]$ arginine $(18.4 \mathrm{mmol})$ was administered to patient 10 , both before (day 0 ) and after (day 6 ) the induction course of IL-2, as shown in Fig. 3, panels $c-e$. A total of $17.6 \mu \mathrm{mol}$ of $\left[{ }^{15} \mathrm{~N}^{-N^{-}} \mathrm{O}_{3}^{-}\right.$and a total of $3.1 \mathrm{mmol}$ of $\left[{ }^{15} \mathrm{~N}\right]$ urea (derived from $0.1 \%$ and $17 \%$, respectively, of the $\mathrm{L}-\left[{ }^{15} \mathrm{~N}\right]$ arginine molecules infused) were excreted in the urine during the subsequent 24-h period (day 1). The second infusion of $L-\left[{ }^{15} \mathrm{~N}\right]$ arginine was ad- 


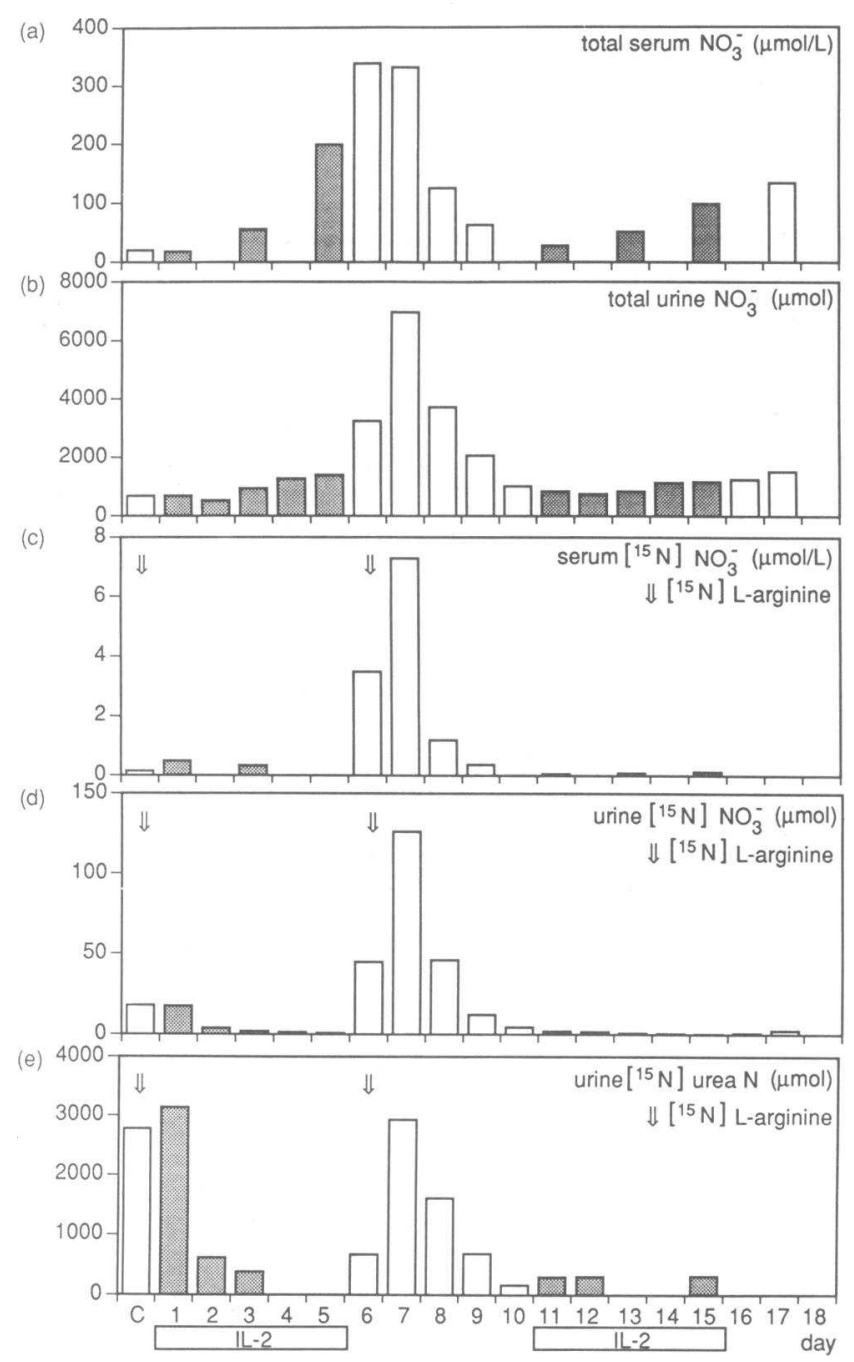

Figure 3. $\left[{ }^{15} \mathrm{~N}^{-N^{-}}{ }_{3}^{-}\right.$and $\left[{ }^{15} \mathrm{~N}\right]$ urea excretion and serum $\left[{ }^{15} \mathrm{~N}\right] \mathrm{NO}_{3}^{-}$ values by patient 10 administered L- $\left[{ }^{15} \mathrm{~N}_{2}\right]$ arginine $\mathrm{HCl}$ (arrows). See legend to Fig. 2 for an explanation of the symbols. Panels $a$ and $b$ show total serum $\mathrm{NO}_{3}^{-}$levels and 24-h urinary $\mathrm{NO}_{3}^{-}$excretion, respectively. Patient 10 received two $3.9-\mathrm{g}(18.4 \mathrm{mmol})$ infusions of $\mathrm{L}-$ $\left[{ }^{15} \mathrm{~N}\right]$ arginine. The first was administered during the 24 -h period before beginning induction IL-2 therapy (day 0 ) and again during the 24-h period immediately after terminating induction IL-2 therapy (day 6). L, liter.

ministered to patient 10 after completion of the induction course of IL-2 on day 6 . There were $126 \mu \mathrm{mol}$ of $\left[{ }^{15} \mathrm{~N}_{\mathrm{NOO}}^{-}\right.$and $2.9 \mathrm{mmol}$ of $\left[{ }^{15} \mathrm{~N}\right]$ urea (derived from $0.7 \%$ and $16 \%$, respectively, of $\mathrm{L}-\left[{ }^{15} \mathrm{~N}\right]$ arginine infused) excreted in the urine during the $24-\mathrm{h}$ period after the $\mathrm{L}-\left[{ }^{15} \mathrm{~N}\right]$ arginine infusion was terminated (day 7). This represented a seven-fold increase in incorporation of ${ }^{15} \mathrm{~N}$-labeled terminal guanidino nitrogen atoms of $\mathrm{L}$ arginine into urine $\left[{ }^{15} \mathrm{~N}_{3} \mathrm{NO}_{3}^{-}\right.$and no change in the synthesis of $\left[{ }^{15} \mathrm{~N}\right]$ urea after the $5-\mathrm{d}$ induction course of IL-2.

The synthesis of unlabeled $\mathrm{NO}_{3}^{-}$and urea- $\mathrm{N}$ from endogenous sources of $\mathrm{L}$-arginine was compared to the synthesis of $\left[{ }^{15} \mathrm{~N}\right] \mathrm{NO}_{3}^{-}$and $\left[{ }^{15} \mathrm{~N}\right]$ urea- $\mathrm{N}$ from $\mathrm{L}-\left[{ }^{15} \mathrm{~N}\right]$ arginine infused before and after administration of the induction course of IL-2 to patient 10 (see Fig. 3). This analysis determines the percentage of total urea and $\mathrm{NO}_{3}^{-}$molecules in the 24-h urine sample containing ${ }^{15} \mathrm{~N}$ label derived from $\mathrm{L}-\left[{ }^{15} \mathrm{~N}\right]$ arginine. Unlabeled $24-\mathrm{h}$ urinary urea-N increased from a pretreatment level of 321 $\mathrm{mmol} / 24 \mathrm{~h}$ to a post-IL-2 treatment level of $430 \mathrm{mmol} / 24 \mathrm{~h}$. The corresponding values for ${ }^{15} \mathrm{~N}$-labeled urea- $\mathrm{N}$ was 3.1 mmol on day 1 and $2.9 \mathrm{mmol}$ on day 7 resulting in a ratio of ${ }^{15} \mathrm{~N}$-labeled to unlabeled urea-N of $0.97 \%\left(3.1 \mathrm{mmol}\left[{ }^{15} \mathrm{~N}\right]\right.$ urea$\mathrm{N} / 321 \mathrm{mmol}$ urea- $\mathrm{N} \times 100)$ and $0.67 \%\left(2.9 \mathrm{mmol}\left[{ }^{15} \mathrm{~N}\right]\right.$ urea$\mathrm{N} / 430 \mathrm{mmol}$ urea-N $\times 100$ ) on days 1 and 7 , respectively. Corresponding measurements of urinary $\mathrm{NO}_{3}^{-}$demonstrated a 10-fold increase of $24 \mathrm{~h}$ urine $\mathrm{NO}_{3}^{-}$derived from endogenous sources of L-arginine (669 mmoles $\mathrm{NO}_{3}^{-}$on day 1 and 6,848 mmol NO${ }_{3}^{-}$on day 7) and a sevenfold increase of labeled $\left[{ }^{15} \mathrm{~N}\right]-$ $\mathrm{NO}_{3}^{-}$(17.6 mmol on day 1 and $126.2 \mathrm{mmol}$ on day 7) during IL-2 treatment. The ratio of labeled and unlabeled urinary $\left[{ }^{15} \mathrm{~N} \mathrm{NO}_{3}^{-}\right.$was $2.6 \%\left(17.6 \mathrm{mmol}\left[{ }^{15} \mathrm{~N}^{\mathrm{N} O} \mathrm{NO}_{3}^{-} / 669 \mathrm{mmol} \mathrm{NO}-\right.\right.$ $\times 100)$ and $1.8 \%\left(126.2 \mathrm{mmol}\left[{ }^{15} \mathrm{~N}^{2} \mathrm{NO}_{3}^{-} / 6,848 \mathrm{mmol} \mathrm{NO}_{3}^{-}\right.\right.$ $\times 100$ ) on days 1 and 7 , respectively. These results show that a similar proportion of total urea and total $\mathrm{NO}_{3}^{-}$molecules excreted in the 24-h urine sample contained ${ }^{15} \mathrm{~N}$ label derived from $\mathrm{L}-\left[{ }^{15} \mathrm{~N}\right]$ arginine (pre- and post-IL-2).

Fig. 3, panel $c$, shows serum $\left[{ }^{15} \mathrm{~N}^{2} \mathrm{NO}_{3}^{-}\right.$levels in patient 10 . After the pre-IL-2 treatment infusion of $\mathrm{L}-\left[{ }^{15} \mathrm{~N}\right]$ arginine the serum $\left[{ }^{15} \mathrm{~N}\right] \mathrm{NO}_{3}^{-}$concentration reached a maximum of 0.5 $\mu \mathrm{mol} /$ liter (day 1). However, the serum $\left[{ }^{15} \mathrm{~N}_{\mathrm{NO}}-\right.$ of patient 10 was $3.5 \mu \mathrm{mol} / \mathrm{liter}\left(1 \%\right.$ of $354 \mu \mathrm{mol} /$ liter total serum $\mathrm{NO}_{3}^{-}$) $12 \mathrm{~h}$ after starting the $\mathrm{L}-\left[{ }^{15} \mathrm{~N}\right]$ arginine infusion (day 6). Immediately after terminating the $\mathrm{L}-\left[{ }^{15} \mathrm{~N}\right]$ arginine infusion (day 7 ), the serum $\left[{ }^{15} \mathrm{~N}^{-N^{-}}\right.$was $7.3 \mu \mathrm{mol} / \mathrm{liter}(2.2 \%$ of $331 \mu \mathrm{mol} / \mathrm{liter}$ total serum $\mathrm{NO}_{3}^{-}$) and declined thereafter.

A second patient was administered $L_{-}\left[{ }^{15} \mathrm{~N}\right]$ arginine. The results confirmed that the IL-2-induced increase in urine and serum $\mathrm{NO}_{3}^{-}$was derived from a terminal guanidino nitrogen atom of L-arginine (data not shown). In summary, the ${ }^{15} \mathrm{~N}$-labeling studies demonstrate that (a) IL-2 induces a marked increase in synthesis of $\mathrm{NO}_{3}^{-}$but not urea from a terminal guanidino nitrogen atom of L-arginine, and $(b)$ the ratio of ${ }^{15} \mathrm{~N}$-labeled molecules to unlabeled molecules remains constant regardless of whether synthesis was enhanced by IL- $2\left(\mathrm{NO}_{3}^{-}\right)$or whether synthesis remained relatively unaltered (urea).

Effects of IL-2 on peripheral vascular resistance and renal tubular function. Despite progressive declines in creatinine clearance (days 3-6; panel a), Fig. 4 (left) urine output of RCC patients receiving IL-2 was maintained with intravenous fluids, albumin infusions, furosemide, and dopamine as needed. Mean blood pressure (panel $e$ ) fell from $85 \pm 4$ before IL-2 therapy to a nadir of $67 \pm 3 \mathrm{mmHg}(P<0.004)$ by day 4 . This IL-2-induced decrease in creatinine clearance and blood pressure was associated with a marked increase in weight (from $69 \pm 5.2$ to $73.7 \pm 5.7 \mathrm{~kg}$ on day 6 and profound reversible sodium retention (see Fig. 4, left, panel $b, P<0.001$ ). $2 \mathrm{~d}$ after discontinuation of IL-2, urine volume rose strikingly (from $1.9 \pm 0.5$ on day 6 to $4.2 \pm 0.6 \operatorname{liter} / 24 \mathrm{~h}$ on day $7 ; P<0.001$ ). This diuresis persisted until day 11 , when the second course of IL-2 was begun. Predictably, body weight fell and creatinine clearance and blood pressure rose simultaneously (both $P<$ 0.01 ). The second course of IL-2 produced a similar decrease in urine output and milder fall in blood pressure and again caused salt and water retention and thus weight gain. All alterations were readily reversible when IL-2 was discontinued. Both panels $c$ of Fig. 4 illustrate the FE of urea, another variable that can be used to assess changes in tubular reabsorption. Within $3 \mathrm{~d}$ of beginning IL-2 therapy, FE of urea decreased modestly, rose as 
IL-2 was discontinued, and fell again when IL-2 was readministered. This pattern demonstrates that IL-2 caused both enhanced $\mathrm{Na}$ and urea reabsorption. Panel $d$ of Fig. 4 (left) depicts the urine to plasma ratio of creatinine. As creatinine clearance and sodium excretion declined with IL-2 therapy (days 3-5), the urine to plasma ratio of creatinine fell from $40.7 \pm 4.4$ to $23.3 \pm 9.8(P<0.003)$. A further decrease to a low of $11.2 \pm 3.2$ occurred by day 7 , a time when IL- 2 had been discontinued and when creatinine clearance, blood pressure, urine volume, and salt excretion increased dramatically.

Readministration of IL-2 on day 11 raised the urine to plasma ratio of creatinine to $70.1 \pm 3.0(P<0.001))$. Taken together, these data demonstrate that proximal renal tubular function and the urinary concentrating capacity of patients with unilateral nephrectomies were preserved and not grossly affected by IL-2.

Fig. 4 (right) summarizes the corresponding data from the MM patients. In general, the hemodynamic and renal responses to IL-2 administration were similar to those observed in RCC patients. It is of note, however, that virtually all functional changes were less severe when compared to those in RCC patients, whose baseline renal function was reduced because of prior unilateral nephrectomy. Finally, there was no evidence of major nephrogenous $\mathrm{NO}_{3}^{-}$production in either $\mathrm{MM}$ or RCC patients. The $\mathrm{FE}$ of $\mathrm{NO}_{3}^{-}$(panels $f$ in Fig. 2) was never greater than $\sim 40 \%$ indicating that $\sim 60 \%$ of the filtered $\mathrm{NO}_{3}^{-}$was reabsorbed. Significant renal vascular or tubular $\mathrm{NO}_{3}^{-}$ production during IL-2 therapy would have caused the FE of $\mathrm{NO}_{3}^{-}$to rise further.

\section{Discussion}

In 1981 Green and co-workers (48), while studying the biology of nitrosamine carcinogenesis, reported metabolic balance studies that showed that conventional and germ-free rats synthesize $\mathrm{NO}_{3}^{-}$. This confirmed an earlier study suggesting that mammals, in addition to certain procaryotes, synthesized inorganic nitrogen oxides (49). These workers also investigated $\mathrm{NO}_{3}^{-}$metabolism in long-term metabolic balance studies on healthy humans (47). During one of these studies a human subject on a low $\mathrm{NO}_{3}^{-}$diet developed an unexpected increase of $\mathrm{NO}_{3}^{-}$biosynthesis that occurred simultaneously with the onset of fever and diarrhea (50). Compared to baseline levels, urinary $\mathrm{NO}_{3}^{-}$excretion increased ninefold during the illness. After this observation, Wagner et al. examined the effect of lipopolysaccharide (LPS) treatment on $\mathrm{NO}_{3}^{-}$excretion in rats (51). The results showed that LPS caused a marked (ninefold) increase in $\mathrm{NO}_{3}^{-}$ excretion. Stuehr and Marletta (52) followed up these observations with experiments that demonstrated that murine macrophages cultured in vitro and exposed to LPS synthesized $\mathrm{NO}_{2}^{-}$ and $\mathrm{NO}_{3}^{-}$. These studies defined inorganic nitrogen oxide syn-
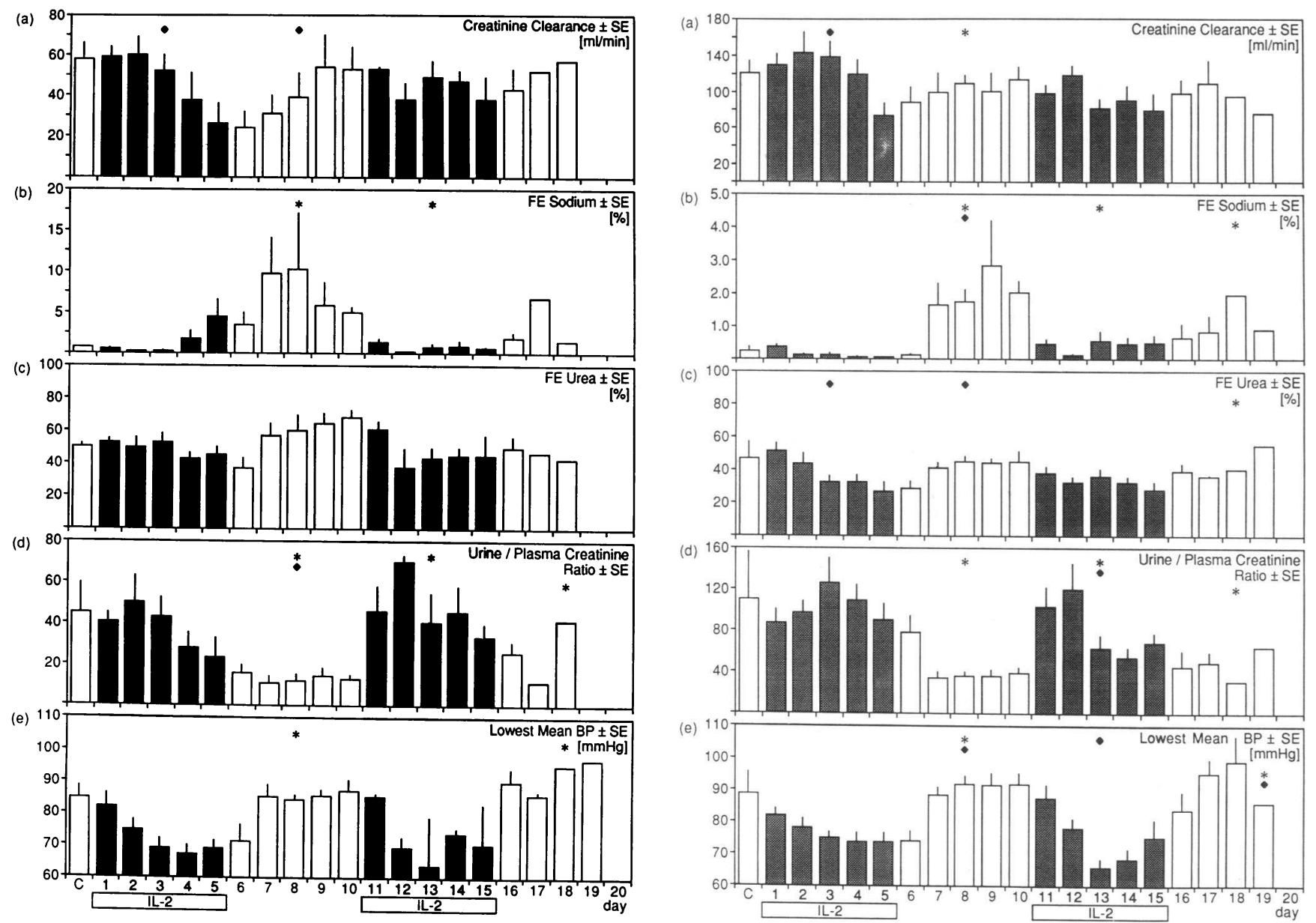

Figure 4. Renal function and blood pressure in (left) RCC patients $(n=5)$ and (right) MM patients $(n=7)$ treated with two courses of IL-2. See legend to Fig. 2 for details and explanation of the symbols. 
thesis as a mammalian process but left open the question of precursor molecule identity and biological significance.

In 1987 our laboratory reported that L-arginine was the only amino acid in the culture medium required by cytotoxic activated macrophages to inhibit DNA replication and to cause inhibition of mitochondrial (4Fe-4S) enzymes in tumor target cells (11). L-Arginine was converted to $\mathrm{NO}_{2}^{-}$and L-citrulline without loss of the guanidino carbon atom (12). These experiments identified L-arginine as the precursor molecule for mammalian inorganic nitrogen oxide synthesis, L-citrulline as an additional product, and established a role for the L-arginine/ NO pathway as an effector mechanism of cell-mediated immunity. NO was then demonstrated to be the precursor of the $\mathrm{NO}_{2}^{-}$ and $\mathrm{NO}_{3}^{-}$previously shown to be synthesized from $\mathrm{L}$-arginine by activated macrophages $(13,15,16)$. In 1987 , two vascular physiology laboratories reported that NO released by endothelial cells accounted for the biological activity of endotheliumderived relaxing factor $(53,54)$. This was followed by a second report in 1988 that demonstrated that NO synthesized by endothelial cells is also derived from a terminal guanidino nitrogen atom of L-arginine (30). Therefore, similar L-arginine/NO pathways were shown to exist in cytotoxic activated macrophages and endothelial cells but the pathways appeared to have been adapted for different physiological functions (e.g., a cytokine-inducible isoenzyme that synthesizes large quantities of NO during cell-mediated immune responses and a constitutive isoenzyme that synthesizes small quantities of NO that functions as an intercellular message).

There is limited information to date on L-arginine/NO pathways in humans. The metabolic balance studies of Green et al. demonstrated that normal adult humans with unrestricted activity endogenously produce $\sim 690 \mu \mathrm{mol}$ of nitrate/ $24 \mathrm{~h}$ (47). After the discovery of the L-arginine/NO pathways, this basal endogenous synthesis was explained by activity of the constitutive low-output NO synthase in maintenance of vascular tone (30), neural transmission (31-33), and in other functions such as chemotaxis (55). NO appears to be an important regulator of resting and stimulated regional blood flow in humans. $\mathrm{N}^{\mathrm{G}}$ monomethyl-L-arginine, a potent inhibitor of both NO-synthesizing pathways $(11,12,30)$, was infused into the brachial arteries of healthy volunteers to study the role of NO in the control of forearm blood flow (56). This agent caused a $50 \%$ fall in basal blood flow and attenuated the dilator response to acetylcholine but not to glycerol trinitrate. Taken together these studies provided evidence for the existence of a constitutive pathway in humans. Until now clinical studies evaluating human subjects for cytokine-inducible NO synthase activity have not been performed. We and others have not been successful in inducing high-output NO synthesis from human cells cultured in vitro by treatment protocols with cytokines that are highly effective with rodent cells (57; Hibbs et al., unpublished data). However, a recent report describes the induction of highoutput nitrite synthesis by cytokine-treated human blood monocyte-derived macrophages infected with Mycobacterium avium (29). The reason why it is difficult to detect activity of the cytokine-inducible pathway in human cells in vitro is not clear. However, results reported in this study demonstrate that IL-2 is a potent inducer of high-output NO synthesis from L-arginine in human subjects with advanced malignancy.

There is evidence to suggest the IL-2 may not directly induce toxic effects or antitumor effects but may act as a factor that mobilizes and amplifies cell-mediated immunity by induc- ing the synthesis of other cytokines (2-7). Elevated levels of IFN $\gamma$ and TNF have been detected in the serum of patients receiving IL-2 (2, 3, 5-7). Furthermore, the peak serum levels of these three cytokines induced by IL-2 infusions in humans occurred at the same time that we measured maximum serum $\mathrm{NO}_{3}^{-}$excretion in the current study. It is of interest that IFN $\gamma$, TNF (serum concentrations) and IL-1 (elevated mRNA) measured in patients administered IL-2 $(2,3,5-7)$ are known to induce the high-output NO synthase in rodents $(17,18,58-62)$. Full induction of the high-output NO synthase in murine macrophages is known to require IFN $\gamma$ and a cosignal, such as LPS or TNF $(17,18)$. The high-output NO synthase also can be induced in nonmacrophage rodent cells including tumor cells $(58,59)$, fibroblasts $(58,60)$, hepatocytes $(61)$, and endothelial cells (62) by IFN $\gamma$ plus TNF (IL-1 is also a cosignal in the case of nonmacrophage rodent cells $[58,60])$. In human subjects, IL-2 therapy induces cytokines (IFN $\gamma$, TNF, and IL-1) known to activate the high-output NO synthase in macrophage and nonmacrophage rodent cells. Therefore, it is possible that the increased $\mathrm{NO}_{3}^{-}$measured in the current study is derived from high-output NO synthesis induced by IFN $\gamma$, TNF, and IL-1 in multiple cell types that include macrophages, endothelial cells, fibroblasts, hepatocytes, and tumor cells.

Two normal human volunteers with unrestricted activity were reported to excrete 24 and $17 \mathrm{mmol}$ of urinary $\left[{ }^{15} \mathrm{~N}^{\mathrm{N} O} \mathrm{NO}_{3}^{-}\right.$ during the 24-h period after the oral administration of $\mathrm{L}-\left[{ }^{15} \mathrm{~N}\right]-$ arginine (the total dose of $\mathrm{L}-\left[{ }^{15} \mathrm{~N}\right]$ arginine was not given) (63). This observation provides further evidence for the synthesis of $\mathrm{NO}_{3}^{-}$from L-arginine in humans, probably, in this case, by the constitutive low-output NO synthase. The current study demonstrates that the marked increase of serum and urine $\mathrm{NO}_{3}^{-}$ induced by IL-2 administration is also derived from a terminal guanidino nitrogen atom of L-arginine. Patients were maintained on TPN $\left(\mathrm{NO}_{2}^{-} / \mathrm{NO}_{3}^{-}\right.$-free) or on a low- $\mathrm{NO}_{3}^{-}$diet throughout the treatment course. However, the patients were administered virtual exclusive TPN during the 5-d courses of IL-2 as well as on days 6 and 7 after induction therapy (see Fig. 2) because of IL-2-associated anorexia, nausea, vomiting, and diarrhea. The use of parenteral $\mathrm{L}-\left[{ }^{15} \mathrm{~N}\right]$ arginine eliminated possible $\left[{ }^{15} \mathrm{~N}^{-N^{-}} \mathrm{O}_{3}^{-}\right.$synthesis from oral $\mathrm{L}-\left[{ }^{15} \mathrm{~N}\right]$ arginine by intestinal microflora. Patient activity was confined to a hospital room (bed rest) which minimized any possible effects of exercise related vasodilation. The results of our study show increased incorporation of terminal guanidino nitrogen atoms of L-arginine into $\mathrm{NO}_{3}^{-}$during IL-2 therapy. This increased incorporation of ${ }^{15} \mathrm{~N}$ into $\mathrm{NO}_{3}^{-}$without increased incorporation into urea is strong evidence for the existence of a human cytokine-inducible high-output NO synthase.

For our small series of patients, the clinical response to IL-2 therapy could not be correlated with the pattern of $\mathrm{NO}_{3}^{-}$production. Further work is required to determine whether activity of the cytokine-inducible high-output L-arginine/NO pathway contributes a neutral, positive, or negative effect to IL-2-mediated tumor regression. However, NO must be considered a candidate effector molecule capable of causing or mediating cytostatic antitumor effects $(11-13,58)$. This reactive molecule may also contribute significantly to certain toxic effects observed in patients receiving IL-2 therapy, such as hypotension. This is supported by partial abrogation of IL-2-induced toxicity in mice by passive immunization against TNF (4), one of the signals required to activate the inducible NO synthase (monoclonal antibodies to TNF have a similar protective effect 
against bacteremic shock [64]). Further support for this concept is derived from recent reports that NO may mediate TNFinduced vascular changes. $\mathrm{N}^{\mathrm{G}}$-monomethyl-L-arginine reversed TNF (65) and endotoxin (66) induced decreased peripheral vascular resistance and mean arterial pressure in dogs. These studies provide evidence for a role for NO in the pathogenesis of decreased vascular resistance and hypotension observed in LPS- or TNF-treated dogs. It also has been demonstrated recently that IL-1 induces L-arginine-dependent cyclic GMP and NO production in rat vascular smooth muscle cells (67). Therefore, it is reasonable to suggest that NO synthesis from L-arginine could play a major role in development of decreased vascular resistance and hypotension in IL-2-treated patients.

The current study provided an opportunity to evaluate renal function in humans under pathophysiological conditions that closely simulate endotoxin/LPS induced shock (hypotension and renal hypoperfusion) in a clinical setting associated with elevated levels of TNF in tissues. The data are consistent with the suggestion made by Marsden and Ballermann (68) that TNF-induced NO produced within the renal parenchyma actually protects against development of acute tubular necrosis by maintaining postglomerular circulation. This is also consistent with the observation that synthesis of NO from L-arginine lessens hepatic damage in a murine model of endotoxin-induced shock (69). NO reduces renal vascular resistance and inhibits platelet activation (aggregation and adhesion [70, 71]). Thus NO has the potential to promote maintenance of renal perfusion under normal and pathological conditions $(30,53$, 54, 70-74). It is likely that cyclic GMP, a second messenger induced by NO, is elaborated by the kidney during IL-2 therapy $(68,73,74)$. It has been shown that atrial natriuretic factor, a peptide with vasodilating and diuretic/natriuretic properties, ameliorates, via cyclic GMP, the severity of acute renal failure $(75,76)$.

The reversible form of IL-2-induced acute renal failure differs significantly from that observed in endotoxemic patients and animals (77-82). In the latter, acute and sometimes irreversible tubular necrosis is common. Specifically patients with endotoxin-induced acute tubular necrosis lose their capacity to retain salt (high FE of sodium) and to concentrate their urine (low urine to plasma creatinine ratio). These alterations were not observed in the IL-2-treated patients evaluated in this study (see Fig. 4). Since IL-2-treated patients resemble patients with endotoxemia in many regards (elevated TNF levels, hypotension, elevated cytokine levels, etc.), it is of interest that acute tubular necrosis is a rare consequence of IL-2 therapy. This observation is even more surprising since all patients received indomethacin, an agent that predisposes to the development of acute tubular necrosis (83). In conclusion, the results reported here show highly significant $\mathrm{NO}_{3}^{-}$synthesis in patients receiving IL-2 therapy for advanced malignancy, and demonstrate that a cytokine-inducible high output L-arginine/NO pathway exists in humans.

\section{Acknowledgments}

We are grateful to the nursing staff of the Clinical Research Center as well as to Renee Christensen for expert assistance and to Colleen Sizemore for typing the manuscript.
This study was supported by the Department of Veterans Affairs Clinical and Research Funds (Drs. Hibbs, Westenfelder, and Samlowski); American Cancer Society grant RD-323 (Dr. Hibbs), National Kidney Foundation of Utah, American Heart Association of Utah and Ogden, Dialysis Research Foundation (Drs. Westenfelder and Baranowski); Baxter Research Foundation (Drs. Kablitz and Baranowski); and by grants from the National Institutes of Health to the Clinical Research Center (RR-00064) and the Utah Regional Cancer Center (CA-42014).

\section{References}

1. Mertelsmann, R., and K. Welte. 1986. Human interleukin-2 molecular biology, physiology and clinical possibilities. Immunobiology. 172:400-419.

2. Gemlo, B. T., M. A. Palladino, Jr., H. S. Jaffe, T. P. Espevik, and A. A. Rayner. 1988. Circulating cytokines in patients with metastatic cancer treated with recombinant interleukin 2 and lymphokine-activated killer cells. Cancer Res. 48:5864-5867.

3. Mier, J. W., G. Vachino, J. W. M. Van Der Meer, R. P. Numerof, S. Adams, J. G. Cannon, H. A. Bernheim, M. B. Atkins, D. R. Parkinson, and C. A. Dinarello. 1988. Induction of circulating tumor necrosis factor (TNFa) as the mechanism for the febrile response to interleukin-2 (IL-2) in cancer patients. $J$. Clin. Immunol. 8:426-436.

4. Fraker, D. L., H. N. Langstein, and J. A. Norton. 1989. Passive immunization against tumor necrosis factor partially abrogates interleukin 2 toxicity. $J$. Exp. Med. 170:1015-1020.

5. Blay, J-Y., M. C. Favrot, S. Negrier, V. Combaret, S. Chouaib, A. Mercatello, P. Kaemmerlen, C. R. Franks, and T. Philip. 1990. Correlation between clinical response to interleukin 2 therapy and sustained production of tumor necrosis factor. Cancer Res. 50:2371-2374.

6. Boccoli, G., R. Masciulli, E. M. Ruggeri, P. Carlini, G. Giannella, E. Montesoro, G. Mastroberardino, G. Isacchi, U. Testa, F. Calabresi, et al. 1990. Adoptive immunotherapy of human cancer: the cytokine cascade and monocyte activation following high-dose interleukin 2 bolus treatment. Cancer Res. 50:57955800.

7. Kasid, A., E. P. Director, and S. A. Rosenberg. 1989. Induction of endogenous cytokine-mRNA in circulating peripheral blood mononuclear cells by IL-2 administration to cancer patients. J. Immunol. 143:736-739.

8. Lotze, M. T., E. A. Grimm, A. Mazumder, J. L. Strausser, and S. A. Rosenberg. 1981. Lysis of fresh and cultured autologous tumor by human lymphocytes cultured in T-cell growth factor. Cancer Res. 41:4420-4425.

9. Mule, J. J., S. Shu, S. L. Schwarz, and S. A. Rosenberg. 1984. Adoptive immunotherapy of established pulmonary metastases with LAK cells and recombinant interleukin-2. Science (Wash. DC). 225:1487-1489.

10. Rosenberg, S. A., M. T. Lotze, and J. J. Mule. 1988. New approaches to the immunotherapy of cancer using interleukin-2. Ann. Intern. Med. 108:853864.

11. Hibbs, J. B., Jr., Z. Vavrin, and R. R. Taintor. 1987. L-arginine is required for expression of the activated macrophage effector mechanism causing selective metabolic inhibition in target cells. J. Immunol. 138:550-565.

12. Hibbs, J. B., Jr., R. R. Taintor, and Z. Vavrin. 1987. Macrophage cytotoxicity: role for L-arginine deiminase and imino nitrogen oxidation to nitrite. Science (Wash. DC). 235:473-476.

13. Hibbs, J. B., Jr., R. R. Taintor, Z. Vavrin, and E. M. Rachlin. 1988. Nitric oxide: A cytotoxic activated macrophage effector molecule. Biochem. Biophys. Res. Commun. 157:87-94. (Erratum published 1989. Biochem. Biophys. Res. Commun. 158:624)

14. Iyengar, R., D. J. Stuehr, and M. A. Marletta. 1987. Macrophage synthesis of nitrite, nitrate, and $N$-nitrosamines: precursors and role of the respiratory burst. Proc. Natl. Acad. Sci. USA. 84:6369-6373.

15. Marletta, M. A., P. S. Yoon, R. Iyengar, C. D. Leaf, and J. S. Wishnock. 1988. Macrophage oxidation of $\mathrm{L}$-arginine to nitrite and nitrate: nitric oxide is an intermediate. Biochemistry. 27:8706-8711.

16. Stuehr, D. J., and C. F. Nathan. 1989. Nitric oxide. A macrophage product responsible for cytostasis and respiratory inhibition in tumor target cells. $J$. Exp. Med. 169:1543-1555.

17. Drapier, J.-C., J. Wietzerbin, and J. B. Hibbs, Jr. 1988. Interferon- $\gamma$ and tumor necrosis factor induce the L-arginine-dependent cytotoxic effector mechanism in murine macrophages. Eur. J. Immunol. 18:1587-1592.

18. Ding, A. H., C. F. Nathan, and D. J. Stuehr. 1988. Release of reactive nitrogen intermediates and reactive oxygen intermediates from mouse peritoneal macrophages. J. Immunol. 141:2407-2412.

19. Hibbs, J. B., Jr., R. R. Taintor, Z. Vavrin, D. L. Granger, J.-C. Drapier, I. J. Amber, and J. R. Lancaster, Jr. 1990. Synthesis of nitric oxide from a terminal guanidino nitrogen atom of L-arginine: a molecular mechanism regulating 
cellular proliferation that targets intracellular iron. In Nitric Oxide from L-Arginine: A Bioregulatory System. S. Moncada and E. A. Higgs editors. Elsevier Science Publishers B. V. (Biomedical Division), New York. 189-223.

20. Nathan, C. F., and J. B. Hibbs, Jr. 1991. Role nitric oxide synthesis in macrophage antimicrobial activity. Curr. Opin. Immunol. 3:65-70.

21. Lancaster, J. R., Jr., and J. B. Hibbs, Jr. 1990. EPR demonstration of iron-nitrosyl complex formation by cytotoxic activated macrophages. Proc. Natl. Acad. Sci. USA. 87:1223-1227.

22. Pellat, C., Y. Henry, and J.-C. Drapier. 1990. IFN- $\gamma$ activated macrophages: detection by electron paramagnetic resonance of complexes between $\mathrm{L}$ arginine-derived nitric oxide and non-heme iron proteins. Biochem. Biophys. Res. Commun. 166:119-125.

23. James, S. L., and J. Glaven. 1989. Macrophage cytotoxicity against schistosomula of Schistosoma mansoni involves arginine-dependent production of reactive nitrogen intermediates. J. Immunol. 143:4208-4212.

24. Granger, D. L., J. B. Hibbs, Jr., J. R. Perfect, and D. T. Durack. 1990. Metabolic fate of $\mathbf{L}$-arginine in relation to microbiostatic capability of murine macrophages. J. Clin. Invest. 85:264-273.

25. Green, S. J., M. S. Meltzer, J. B. Hibbs, Jr., and C. A. Nacy. 1990. Activated macrophages destroy intracellular leishmania major amastigotes by an Larginine dependent killing mechanism. J. Immunol. 144:278-283.

26. Adams, L. B., J. B. Hibbs, Jr., R. R. Taintor, and J. L. Krahenbuhl. 1990 Microbiostatic effect of murine-activated macrophages for Toxoplasma gondii: role for synthesis of inorganic nitrogen oxides from L-arginine. J. Immunol 144:2725-2729.

27. Liew, F. Y., S. Millott, C. Parkinson, R. M. J. Palmer, and S. Moncada 1990. Macrophage killing of Leishmania parasite in vivo is mediated by nitric oxide from L-arginine. J. Immunol. 144:4794-4797.

28. Mauel, J., A. Ransijn, and Y. Buchmuller-Rouiller. 1991. Killing of Leishmania parasites in activated murine macrophages is based on an L-arginine-dependent process that produces nitrogen derivatives. J. Leukocyte Biol. 49:73-82.

29. Denis, M. 1991. Tumor necrosis factor and granulocyte macrophage-colony stimulating factor stimulate human macrophages to restrict growth of virulent mycobacterium avium and to kill avirulent $M$. avium: killing effector mechanism depends on the generation of reactive nitrogen intermediates. J. Leukocyte Biol. 49:380-387.

30. Palmer, R. M. J., D. S. Ashton, and S. Moncada. 1988. Vascular endothelial cells synthesize nitric oxide from L-arginine. Nature (Lond.). 333:664-666.

31. Garthwaite, J., S. L. Charles, and R. Chess-Williams. 1988. Endotheliumderived relaxing factor release on activation of NMDA receptors suggests role as intercellular messenger in the brain. Nature (Lond.). 336:385-388.

32. Knowles, R. G., M. Palacios, R. M. J. Palmer, and S. Moncada. 1989. Formation of nitric oxide from $\mathrm{L}$-arginine in the central nervous system: a transduction mechanism for stimulation of the soluble guanylate cyclase. Proc. Natl. Acad. Sci. USA. 86:5159-5162.

33. Bredt, D. S., P. M. Hwang, and S. H. Snyder. 1990. Localization of nitric oxide synthase indicating a neural role for nitric oxide. Nature (Lond.). 347:768770.

34. Ignarro, L. J. 1989. Heme-dependent activation of soluble guanylate cyclase by nitric oxide: regulation of enzyme activity by porphyrins and metalloporphyrins. Semin. Hematol. 26:63-76.

35. Kosaka, H., K. Imaizumi, K. Imai, and I. Tyuma. 1979. Stoichiometry of the reaction of oxyhemoglobin with nitrite. Biochim. Biophys. Acta. 581:184188

36. Belldegrun, A., D. E. Webb, H. A. Austin III, S. M. Steinberg, D. E. White W. M. Linehan, and S. A. Rosenberg. 1987. Effects of interleukin-2 on rena function in patients receiving immunotherapy for advanced cancer. Ann. Intern. Med. 106:817-822.

37. Kozeny, G. A., J. D. Nicolas, S. Creekmore, L. Sticklin, J. E. Hano, and R. I. Fisher. 1988. Effects of interleukin-2 immunotherapy on renal function. $J$. Clin. Oncol. 6:1170-1176.

38. White, J. W., Jr. 1975. Relative significance of dietary sources of nitrate and nitrite. J. Agric. Food Chem. 23:886-891.

39. Anon. 1981. Nitrate, nitrite and nitrogen oxides: environmental distribution and exposure of humans. In The Health Effects of Nitrate, Nitrite, and $N$-Nitroso Compounds, Volume 1. F. M. Peter, editor. National Academy Press, Washington, DC. 3-52.

40. Bartholomew, B. 1984. A rapid assay of urine nitrate using the nitrate reductase enzyme of Escherichia coli. Food Chem. Toxicol. 22:541-543.

41. Green, L. C., D. A. Wagner, J. Glogowski, P. L. Skipper, J. S. Wishnok, and S. R. Tannenbaum. 1982. Analysis of nitrate, nitrite, and $\left[{ }^{15} \mathrm{~N}\right]$ nitrate in biological fluids. Anal. Biochem. 126:131-138.

42. Tserng, K., and S. C. Kalhan. 1982. Gas chromatography/mass spectrometric determination of $\left[{ }^{15} \mathrm{~N}\right]$ urea in plasma and application to urea metabolism study. Anal. Chem. 54:489-491.

43. Westenfelder, C., F. M. Birch, R. L. Baranowski, J. B. Riebman, D. B. Olsen, G. L. Burns, and C. Kablitz. 1990. Volume homeostasis in calves with artificial atria and ventricles. Am. J. Physiol. 258(Renal Fluid Electrolyte Physiol. 27): F1005-F1017
44. Westenfelder, C., R. K. Hamburger, and M. E. Garcia. 1981. Effect of vanadate on renal tubular function in rats. Am. J. Physiol. 240(Renal Fluid Electrolyte Physiol. 9): F522-F529.

45. Polissar, L., and P. Diehr. 1982. Regression analysis in health services research: the use of dummy variables. Medical Care. 20:959-966.

46. Cohen, J., and P. Cohen. 1983. Applied Multiple Regression/Correlation Analysis for the Behavioral Sciences. Lawrence Erlbaum Associates, Hillsdale, NJ.

47. Green, L. C., K. R. deLuzuriaga, D. A. Wagner, W. Rand, N. Istfan, V. R. Young, and S. R. Tannenbaum. 1981. Nitrate biosynthesis in man. Proc. Natl. Acad. Sci. USA. 78:7764-7768.

48. Green, L. C., S. R. Tannenbaum, and P. Goldman. 1981. Nitrate synthesis in the germfree and conventional rat. Science (Wash. DC). 212:56-58.

49. Mitchell, H. H., H. A. Shonle, and H. S. Grindley. 1916. The origin of the nitrates in the urine. J. Biol. Chem. 24:461-490.

50. Wagner, D. A., and S. R. Tannenbaum. 1982. Enhancement of nitrate biosynthesis by E. coli LPS. In Nitrosamines and Human Cancer. P. N. Magee, editor. Banbury Rep. 12:437-443.

51. Wagner, D. A., V. R. Young, and S. R. Tannenbaum. 1983. Mammalian nitrate biosynthesis: incorporation of ${ }^{15} \mathrm{NH}_{3}$ into nitrate is enhanced by endotoxin treatment. Proc. Natl. Acad. Sci. USA. 80:4518-4521.

52. Stuehr, D. J., and M. A. Marletta. 1985. Mammalian nitrate biosynthesis: mouse macrophages produce nitrite and nitrate in response to Escherichia coli lipopolysaccharide. Proc. Natl. Acad. Sci. USA. 82:7738-7742.

53. Palmer, R. M. J., A. G. Ferrige, and S. Moncada. 1987. Nitric oxide release accounts for the biological activity of endothelium-derived relaxing factor. Nature (Lond.). 327:524-526.

54. Ignarro, L. J., G. M. Buga, K. S. Wood, R. E. Byrns, and G. Chaudhuri. 1987. Endothelium-derived relaxing factor produced and released from artery and vein in nitric oxide. Proc. Natl. Acad. Sci. USA. 84:9265-9269.

55. Schmidt, H. H. H. W., R. Seifert, and E. Bohme. 1989. Formation and release of nitric oxide from human neutrophils and HL-60 cells induced by a chemotactic peptide, platelet activating factor and leukotriene $\mathrm{B}_{4}$. FEBS (Fed. Eur. Biochem. Soc.) J. 244:357-360.

56. Vallance, P., J. Collier, and S. Moncada. 1989. Effects of endotheliumderived nitric oxide on peripheral arteriolar tone in man. Lancet. 2:997-1000.

57. Cameron, M. L., D. L. Granger, J. B. Weinberg, W. J. Kozumbo, and H. S. Koren. 1990. Human alveolar and peritoneal macrophages mediate fungistasis independently of L-arginine oxidation to nitrite or nitrate. Am. Rev. Respir. Dis. 142:1313-1319.

58. Amber, I. J., J. B. Hibbs, Jr., R. R. Taintor, and Z. Vavrin. 1988. Cytokines induce an $\mathrm{L}$-arginine-dependent effector system in nonmacrophage cells. $J$. Leukocyte Biol. 44:58-65.

59. Lepoivre, M., B. Chenais, A. Yapo, G. Lemaire, L. Thelander, and J. P. Tenu. 1990. Alterations of ribonucleotide reductase activity following induction of the nitrite-generating pathway in adenocarcinoma cells. J. Biol. Chem. 265:14143-14149.

60. Werner-Felmayer, G., E. R. Werner, D. Fuchs, A. Hausen, G. Reibnegger, and H. Wachter. 1990. Tetrahydrobiopterin-dependent formation of nitrite and nitrate in murine fibroblasts. J. Exp. Med. 172:1599-1607.

61. Curran, R. D., T. R. Billiar, D. J., Stuehr, K. Hoffmann, and R. L. Simmons. 1989. Hepatocytes produce nitrogen oxides from $L$-arginine in response to inflammatory products of kupffer cells. J. Exp. Med. 170:1769-1774.

62. Kilbourn, R. G., and P. Belloni. 1990. Endothelial cell production of nitrogen oxides in response to interferon $\mathrm{g}$ in combination with tumor necrosis factor, interleukin-1, or endotoxin. J. Natl. Cancer Inst. 82:772-776.

63. Leaf, C. D., J. S. Wishnok, and S. R. Tannenbaum. 1989. L-arginine is a precursor for nitrate biosynthesis in humans. Biochem. Biophys. Res. Commun. 163:1032-1037.

64. Tracey, K. J., Y. Fong, D. G. Hesse, K. R. Manogue, A. T. Lee, G. C. Kuo, S. F. Lowry, and A. Cerami. 1987. Anti-cachectin/TNF monoclonal antibodies prevent septic shock during lethal bacteraemia. Nature (Lond.). 330:662-664.

65. Kilbourn, R. G., S. S. Gross, A. Jubran, J. Adams, O. W. Griffith, R. Levi, and $R$. F. Lodato. 1990. $N^{\mathrm{G}}$-methyl-L-arginine inhibits tumor necrosis factor-induced hypotension: implications for the involvement of nitric oxide. Proc. Natl. Acad. Sci. USA. 87:3629-3632.

66. Kilbourn, R. G., A. Jubran, S. S. Gross, O. W. Griffith, R. Levi, J. Adams, and R. F. Lodato. 1990. Reversal of endotoxin-mediated shock by $N^{G}$-methyl-Larginine, an inhibitor of nitric oxide synthesis. Biochem. Biophys. Res. Commun. 172:1132-1138.

67. Beasley, D., J. H. Schwartz, and B. M. Brenner. 1991. Interleukin 1 induces prolonged $\mathrm{L}$-arginine-dependent cyclic guanosine monophosphate and nitrite production in rat vascular smooth muscle cells. J. Clin. Invest. 87:602-608.

68. Marsden, P. A., and B. J. Ballermann. 1990. Tumor necrosis factor a activated soluble guanylate cyclase in bovine glomerular mesangial cells via an L-arginine-dependent mechanism. J. Exp. Med. 172:1843-1852.

69. Billiar T. R., R. D. Curran, B. G. Harbrecht, D. J. Stuehr, A. J. Demetris, 
and R. L. Simmons. 1990. Modulation of nitrogen oxide synthesis in vivo: $\mathbf{N}^{\mathrm{G}}$ monomethyl-L-arginine inhibits endotoxin-induced nitrite/nitrate biosynthesis while promoting hepatic damage. J. Leukocyte Biol. 48:565-569.

70. Salvemini, D., G. de Nucci, R. J. Gryglewski, and J. R. Vane. 1989. Human neutrophils and mononuclear cells inhibit platelet aggregation by releasing a nitric oxide-like factor. Proc. Natl. Acad. Sci. USA. 86:6328-6332.

71. Radomski, M. W., R. M. J. Palmer, and S. Moncada. 1987. The role of nitric oxide and CGMP in platelet adhesion to vascular endothelium. Biochem. Biophys. Res. Commun. 148:1482-1489.

72. Baylis, C., P. Harton, and K. Engels. 1990. Endothelial derived relaxing factor controls renal hemodynamics in normal rat kidney. J. Am. Soc. Nephrol. 1:875-881.

73. Marsden, P. A., T. A. Brock, and B. J. Ballermann. 1990. Glomerular endothelial cells respond to calcium-mobilizing agonists with release of EDRF. Am. J. Physiol. 258(Renal Fluid Electrolyte Physiol. 27): F1295-F1303.

74. Shultz, P. A., A. E. Schorer, and L. Raij. 1990. Effects of endothelium-derived relaxing factor and nitric oxide on rat mesangial cells. Am. J. Physiol. 258(Renal Fluid Electrolyte Physiol. 27):F162-F167.

75. Shaw, S. G., P. Weidmann, J. Hodler, A. Zimmerman, and A. Paternostro. 1987. Atrial natriuretic factor protects against acute ischemic renal failure in the rat. J. Clin. Invest. 80:1232-1237.

76. Ratcliffe, P. J., A. J. Richardson, L. J. E. Kirby, C. Moyses, J. R. Shelton, and P. J. Morris. 1991. Effect of intravenous infusion of atriopeptin 3 on immediate renal allograft function. Kidney Int. 39:164-168.

77. Kennedy, A. C., J. A. Burton, R. G. Luke, J. D. Briggs, R. M. Lindsay, M. E. Allison, N. Edward, and H. J. Dargie. 1960. Factors affecting the prognosis in acute renal failure. A survey of 251 cases. $Q . J$. Med. 165:73-80.

78. Wardle, N. 1982. Acute renal failure in the 1980s: the importance of septic shock and of endotoxemia. Nephron. 30:190-193.

79. Zager, R. A. 1986. Escherichia coli endotoxin injections potentiate experimental ischemic renal injury. Am. J. Physiol. 251(Renal Fluid Electrolyte Physiol. 20):F988-F994.

80. Walker, P. D., and S. V. Shah. 1990. Reactive oxygen metabolites in endotoxin-induced acute renal failure in rats. Kidney Int. 38:1125-1132.

81. Kikeri, D., J. P. Pennell, K. H. Hwang, A. I. Jacob, A. V. Richman, and J. J. Bourgoignie. 1986. Endotoxemic acute renal failure in awake rats. Am. J. Physiol. 250(Renal Fluid Electrolyte Physiol. 19): F1098-F1 106.

82. Westenfelder, C., G. J. Arevalo, P. W. Crawford, P. Z. Zerwer, R. L Baranowski, F. M. Birch, W. R. Earnest, R. K. Hamburger, R. C. Coleman, and N. A. Kurtzman. 1980. Renal tubular function in glycerol-induced acute renal failure. Kidney Int. 18:432-444.

83. Stoff, J. S., and D. M. Clive. 1983. Role of prostaglandins and thromboxane in acute renal failure. In Acute Renal Failure. B. M. Brenner and J. M. Lazarus, eds. W. B. Saunders Co., Philadelphia, pp. 157-174. 